\title{
LEVOGLUCOSAN EMISSION FROM DIFFERENT INDIGENOUS AND EXOTIC PLANT SPECIES IN BANGLADESH
}

\author{
Jahan, K., F. Jeba, M. S. Islam and A. Salam \\ Department of Chemistry, University of Dhaka, Dhaka-1000, Bangladesh
}

\begin{abstract}
Levoglucosan is a biomarker for biomass burning with high emission efficiency. Both indigenous and exotic plant species (biomass) are common in Bangladesh and used as a fuel source in rural areas for cooking purposes. Three indigenous plants, Mango (Mangifera indica), Jackfruit (Artocarpus heterophyllus), Coconut (Cocos nucifera) and three exotic plants, Mahogany (Swietenia mahagoni), Koroi (Albizia lebbeck), Guava (Psidium guajava), were selected for this experiment. The study was carried out to determine and compare the levoglucosan emission for these selected indigenous and exotic plants upon burning at the typical rural cooking stove in the laboratory scale. $\mathrm{PM}_{10}$ samples were collected on top of the cooking stove using a low volume air sampler (LVAS). The concentration was determined quantitatively by UV-visible spectrophotometer using anthrone-sulfuric acid reagent. The exotic plant samples $\left(7.47 \mathrm{mg} / \mathrm{m}^{3}\right) \mathrm{emitted} \mathrm{a}$ higher concentration of levoglucosan than the indigenous plant samples $\left(6.49 \mathrm{mg} / \mathrm{m}^{3}\right)$. Among the six different leaf samples, $S$. mahagoni leaves showed the highest emission of levoglucosan $\left(6.31 \mathrm{mg} / \mathrm{m}^{3}\right)$ and $C$. nucifera leaves showed the lowest levoglucosan $\left(5.74 \mathrm{mg} / \mathrm{m}^{3}\right)$ due to their individual cellulose content and combustion efficiency. Among the six wood samples, S. mahagoni woods showed the maximum concentration (9.63 $\left.\mathrm{mg} / \mathrm{m}^{3}\right)$ and $C$. nucifera coir showed the minimum concentration $\left(6.631 \mathrm{mg} / \mathrm{m}^{3}\right)$ of levoglucosan emission. The soft leaf samples $\left(6.02 \mathrm{mg} / \mathrm{m}^{3}\right)$ showed lower emission than the hardwood $\left(7.97 \mathrm{mg} / \mathrm{m}^{3}\right)$ samples because of their diverse structural pattern and combustion efficiency. Comparing the emission factors, the exotic wood and leaf samples $\left(\mathrm{EF}=2.89 * 10^{-3} \mathrm{~g} / \mathrm{kg}\right)$ showed higher emission than the indigenous wood and leaf samples $\left(\mathrm{EF}=2.55^{*} 10^{-3} \mathrm{~g} / \mathrm{kg}\right)$.
\end{abstract}

Key words: Levoglucosan; Biomarker; Exotic and indigenous plant species; Biomass burning; Emission factor.

\section{INTRODUCTION}

Biomass combustion is a significant source of air pollution which includes natural as well as anthropogenic forest burning, residential wood fueling, waste disposal burning, etc. These burning practices include numerous species of plants which create a significant volume of smoke that releases many gases, including organic as well as greenhouse gases (e.g. CO2), and also particulate matter (PM) including black carbon (BC), and brown carbon (BrC), etc. (Bhattarai et al. 2019, Cofer et al. 1991). These smoke particles from the burned plant species contain thermally intact and partially damaged biomarker compounds (Fartas et al. 2009). Various organic molecular markers, including levoglucosan, mannosan, galactosan, etc., have been commonly used in recent years (Bhattarai et al. 2019). Levoglucosan is very influential and a major organic product released from the burning of biomass with fine smoke particulate matter (Schmidl et al. 2008). Levoglucosan (C6H10O5) is a 1,6-anhydroderivative of beta-D glucopyranose. It's a human metabolite and a biomarker. Its IUPAC name is (1R,2S,3S,4R,5R)-6,8-dioxabicyclo [3.2.1] octane-2,3,4-triol (Zdrahal et al. 2002).

Levoglucosan is mainly formed during the thermal pyrolysis of cellulose and hemicellulose present in plant species (dos Santos et al. 2002). It is present in the emission of fine particulate matter from the combustion of residential wood in a typical wood stove with an emission rate of $2-18 \mathrm{mg} / \mathrm{min}$. (Simoneit 2002). Janoszka et al. (2020) researched to estimate biomass burning tracer concentrations over two winter seasons in PM10 specimens in Krynica. Amongst identified biomass combustion tracers, Levoglucosan has been the superior precursor with almost 90\%. Jimenez et al. (2017) evaluated the "emission factors (EFs) of particulate matter, polycyclic aromatic hydrocarbons, and levoglucosan from wood combustion in south-central Chile". Higher EFs recorded for levoglucosan due to 
incomplete combustion of wood, regardless of cellulose form. They suggested that the emission of levoglucosan could not only depend on the nature of wood. Bhattarai et al. (2019) reported recent progress and perspective of levoglucosan as a tracer of biomass burning. They indicated that levoglucosan emissions and degradations rely on several external factors, including $\mathrm{pH}, \mathrm{RH}$, temperature, and biological activity. It was proposed that the original levoglucosan content in the emission resource should be measured using both control and environmental conditions by using a more precise calculation of decay continuity and transport time.

The levoglucosan stability is very high in ambient conditions and sunlight over an 8-hour exposure (Larsen et al. 2006, Puxbaum et al. 2007). In acidic conditions, levoglucosan did not decay over ten days (Schkolnik and Rudich 2006). Due to high stability and abundance in the atmosphere from cellulose combustion, levoglucosan is an ideal molecular marker for biomass burning (Simoneit et al. 1999, Fraser and Lakshmanan 2000, Simoneit et al. 2004, Holmes and Petrucci 2007).

Bangladesh is one of the developing and densely populated nations in the world located in South Asia. More than $70 \%$ of the people here live in rural areas (Huda et al. 2014). Rural households use biomass fuels like woods, dry leaf, rice husk, straw, jute stick, bamboo, etc. often collected from the local environment. Woods and dry leaves are usually burned in great quantities for cooking purposes. Numerous numbers of plants grow in South Asia and in Bangladesh that are indigenous. But some plant species are exotic and have become very popular in Bangladesh for timber, crops, and fruits. Local people are planting these exotic plants parallelly with indigenous plants and using woods and leaves as biomass fuel. During the burning of indigenous and exotic plant species there is a lot of smoke containing levoglucosan, a biomarker.

The rise in respiratory and cardiovascular disease including respiratory infections, inflammatory lung diseases, heart disorders, stroke, eye disorders, tuberculosis, cancer, and hospital admissions with associated with air pollution due to fine particulates exposure (Naeher et al. 2007). Levoglucosan is one of Wood Smoke's largest rich organic particulate phase compounds. Levoglucosan exposure particularly generates adverse health effects, including inflammation of the eye, nose, and mouth, disorders of the lung and intensified respiratory infections (Ward and Hardy 1991). It is, therefore, very important for Bangladesh to know the amount of levoglucosan emission from the burning of plant species they are massively used as biomass.

In this study, three indigenous plant species, namely Mango, Jackfruit, Coconut, and three exotic plant species, namely Koroi, Mahogany, and Guava were burned at the typical rural cooking stoves in the laboratory scale. Smokes from the burning were collected to determine concentration of emitted levoglucosan. The aim of this study is to determine levoglucosan concentration during the burning of several indigenous and exotic plant species commonly used for cooking and for other purposes in Bangladesh. Also, to compare between concentration and emission factors of levoglucosan for the burning of indigenous and exotic plant species.

\section{Sample collection}

\section{MATERIAL AND METHODS}

The indigenous and exotic plant samples, including both leaves and woods of Mango, Jackfruit, Coconut, Mahogany, Koroi, and Guava, were obtained from Bhangura upazila (Latitude: $24.13^{\circ} \mathrm{N}$, Longitude: $89.24^{\circ} \mathrm{E}$ ), Pabna district, Bangladesh. The samples were collected manually, kept inside individual plastic carry bags, and transported to the Environmental and Atmospheric Chemistry Laboratory, Mukarram Hussain Khundaker Science Building, Department of Chemistry, University of Dhaka (DU) for carrying out the experiment. The physical properties and origin of the plant samples has given below in Table 1. 


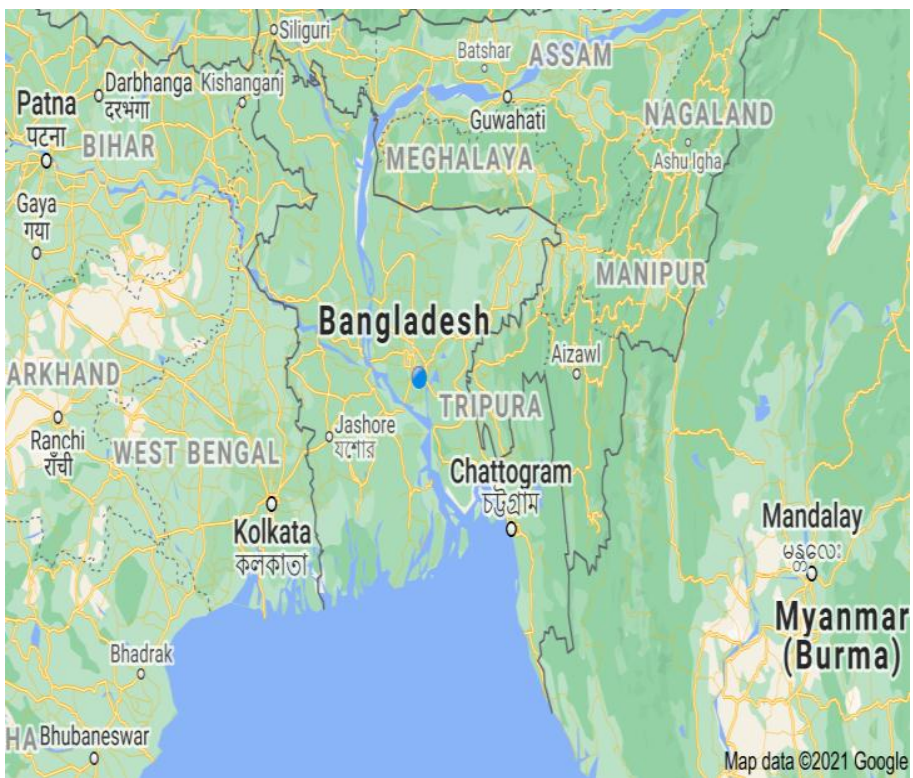

a.

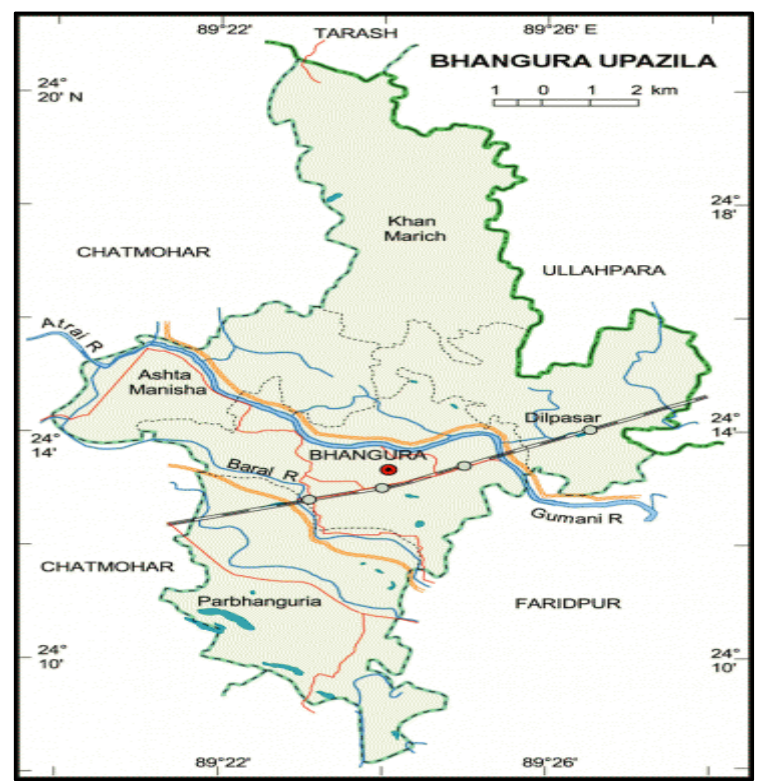

b.

Fig. 1. Sampling site: a. Map of Bangladesh; b).Map of Bhangura upazila Pabna Bangladesh.

\section{Sampling}

Quartz filter papers (Gelman, membrane filters, type tissue quartz 2500 quarts-up, 47mm diameter) were used for collecting particulate matter (PM10) emissions from the burning of the plant samples. Before sampling, the Quartz filter papers were heated for 4 hours at $800^{\circ} \mathrm{C}$ to remove all the organic impurities, then kept in a desiccator to attain room temperature. The plant samples (both woods and leaves) were cut into small pieces, dried and about $250.0 \mathrm{~g}$ of each sample were burned in a typical cooking stove. Approximately $31 \mathrm{~cm}$ above the stove, a sample holder of a low volume air sampler filled with pretreated Quartz filter paper was held to collect particulate matter $\left(\mathrm{PM}_{10}\right)$ emissions for 2.5 minutes. The process was repeated two times. The loaded filter papers were kept in the petri-dish and rapped with aluminum foil. All the loaded filter papers were preserved below $4^{\circ} \mathrm{C}$ in the refrigerator until the extraction process.

\section{Extraction of the samples}

Individually all the filter papers were incised one-fourth with clean scissors and forceps. The incised filter papers were placed in $50.0 \mathrm{ml}$ volumetric flasks and filled up to the mark by deionized water. The mixtures were sonicated for 1 hour at room temperature and settled down for 30.0 minutes. The mixed solutions were then filtered with Whatman-40 filter paper, and the filtrates were used as a stock solution for UV analysis.

\section{Calibration curve}

For preparing anthrone reagent $0.02 \mathrm{~mL}$ of anthrone (9,10-dihydro-9-oxoanthracene) was dissolved in $100.0 \mathrm{~mL}$ concentrated sulfuric acid (97\%). After 45.0 minutes, the reagent was clear. Every day this reagent was prepared freshly and used within 12 hours (Yemm and Wills 1954).

Different standard levoglucosan solutions $(0.05,0.10,0.25,0.50,1.00$ and $1.50 \mathrm{ppm})$ were prepared in $50.0 \mathrm{~mL}$ volumetric flask by deionized water. $10.0 \mathrm{~mL}$ of anthrone reagent was mixed with $5.0 \mathrm{~mL}$ levoglucosan standard solution in a thick-walled Pyrex tube $(150 \times 25 \mathrm{~mm})$. The tube was then transferred to a $100^{\circ} \mathrm{C}$ shaking water bath for 10.0 minutes to produce a green dye. It was kept at $4{ }^{\circ} \mathrm{C}$ for 
5.0 minutes to prevent condensation of moisture during reading and 5.0 minutes in water at $20^{\circ} \mathrm{C}$. Then the UV visible spectrum of the solution was obtained. From the absorbance peak, a maximum wavelength of $340 \mathrm{~nm}$ was obtained. Finally, each solution's absorbance was taken at $340 \mathrm{~nm}$ by UV Visible spectrometer. The calibration curve for different standard levoglucosan solutions has given below in Fig. 2.

Table 1. Physical properties and origin of different indigenous and exotic plant samples.

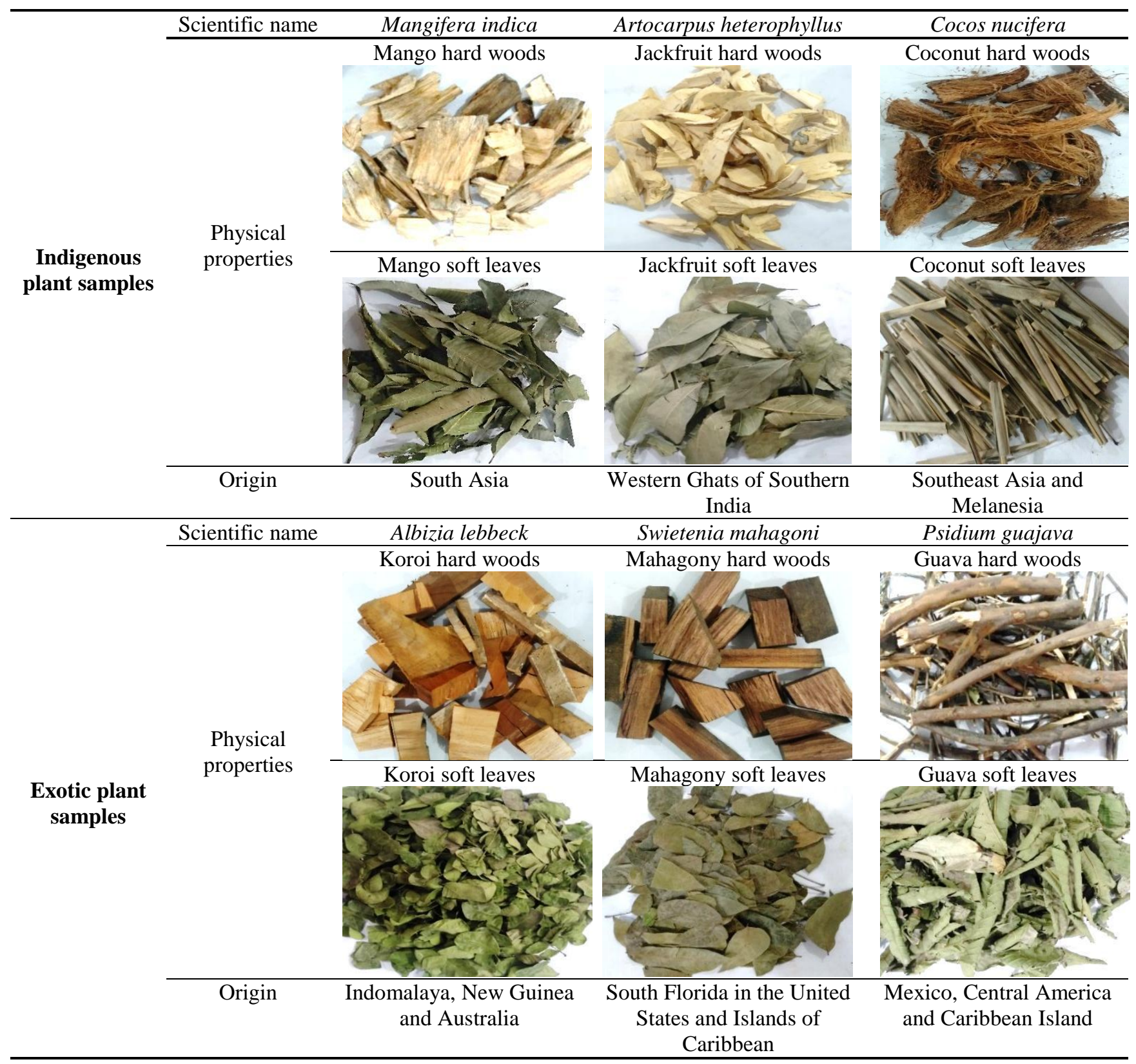

Determination of levoglucosan in indigenous and exotic plant samples

$0.02 \mathrm{~mL}$ of anthrone (9,10-dihydro-9-oxoanthracene) was dissolved in $100.0 \mathrm{~mL}$ concentrated sulfuric acid (97\%). $10.0 \mathrm{~mL}$ of the prepared anthrone solution was transferred to a series of test tubes immersed in an ice water bath. It was carefully over layered with $5.0 \mathrm{~mL}$ of stock solution of different 
plant samples. After these additions had been made, the tubes were shaken rapidly. The tubes were then transferred to a $100^{\circ} \mathrm{C}$ boiling water bath (shaking water bath: JSSB-30T) for 10.0 minutes. It was followed by a $4^{\circ} \mathrm{C}$ ice bath for 5.0 minutes to prevent moisture condensation during reading, finally 5.0 minutes in $20^{\circ} \mathrm{C}$ water. The solution was kept at room temperature, and the absorbance of these solutions was measured within 1-hour by UV-visible spectrometer (UV-1800, Shimadzu, Japan) at $340 \mathrm{~nm}$ against deionized water. This process was performed three times for all the samples.

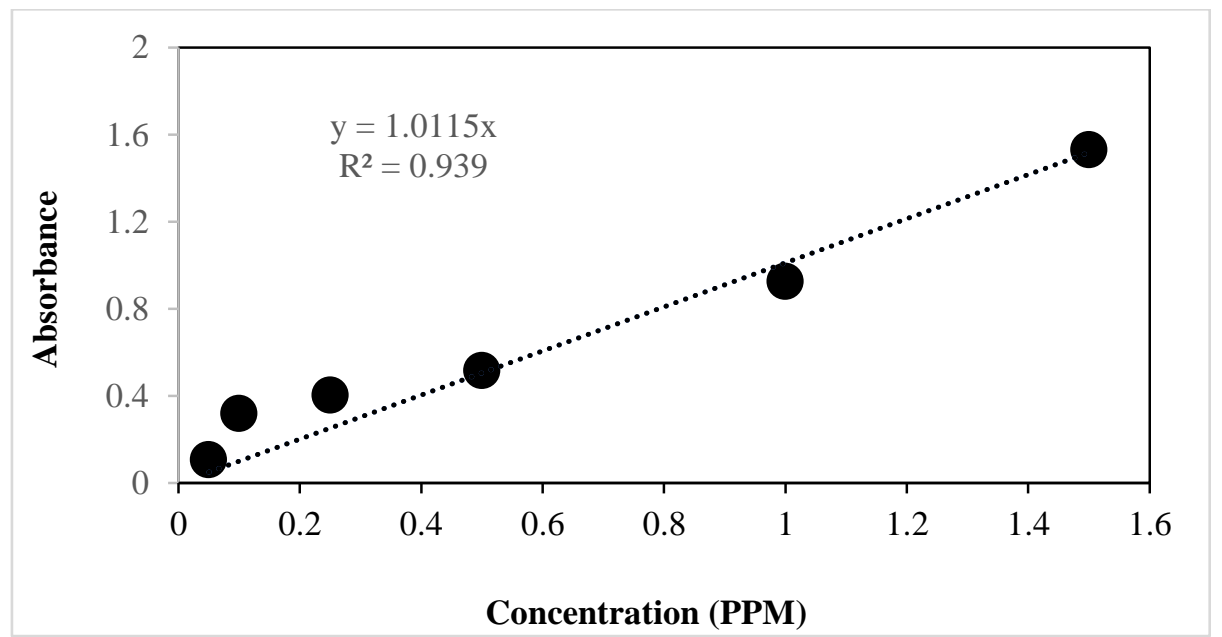

Fig. 2. Absorbance of the standard levoglucosan solution for the Calibration curve.

\section{Conversion of the unit of concentrations}

The conversion factor can be used to express concentrations as parts per million (ppm) or as parts per billion (ppb). The conversion factor is dependent on the molecular weight of the chemical and is different for every chemical. Atmospheric temperature and pressure impact the measurement as well. Conversions for chemical compounds in the air typically require 1 air pressure and a $25^{\circ} \mathrm{C}$ temperature. The equation to be translated from concentration in parts per million to concentration in milligrams per cubic meter $\left(\mathrm{mg} / \mathrm{m}^{3}\right)$ is as follows for these conditions.

Concentration $\left(\mathrm{mg} / \mathrm{m}^{3}\right)=0.0409 \times$ concentration $(\mathrm{ppm}) \times$ molecular weight

(Boguski 2006)

Emission factors were calculated following the previous report of Cooper and Alley 1994. If the flux chamber is mixed, uniform conditions and concentrations in the chamber are required and similar to those in the exit flux.

The EFs were thus determined as follows, $\left.\mathrm{EF}_{\mathrm{x}} \mathrm{g} / \mathrm{kg}=\left(\mathrm{C}_{\mathrm{x}} \times \mathrm{Q}_{\text {chamber }} \times \mathrm{t}_{\text {run }}\right) / 1000 \mathrm{mg} / \mathrm{g} \times \mathrm{m}_{\text {burned }}\right)$

"Where, $\mathrm{EF}_{\mathrm{x}}$ is the emission factor in $\mathrm{g}$ of pollutant $\mathrm{X} \mathrm{kg} \mathrm{kg}^{-1}$ dry stubble burned, $\mathrm{C}_{\mathrm{x}}$ the exit concentration of pollutant $X$ in excess of the background, $\mathrm{mg} / \mathrm{m}^{3}, \mathrm{Q}_{\text {chamber }}$ the flow rate of dilution air into the burn chamber in $\mathrm{m}^{3} \mathrm{~min}^{-1}$, $\mathrm{t}_{\text {run }}$ is the flow time, $\mathrm{m}_{\text {burned }}$ is the amount of sample burned in $\mathrm{kg}$." 


\section{RESULTS AND DISCUSSION}

The absorbance of emitted levoglucosan for the selected plant samples was monitored, and their concentrations were calculated from the calibration curve in $\mathrm{ppm}$ unit and converted to $\mathrm{mg} / \mathrm{m}^{3}$ unit, respectively. The concentration of levoglucosan from selected indigenous and exotic plant species after burning is summarized in Table 2 .

Table 2. Concentration of levoglucosan in indigenous and exotic plant species.

\begin{tabular}{|c|c|c|c|c|c|}
\hline $\begin{array}{l}\text { Plant } \\
\text { species }\end{array}$ & Sample & $\begin{array}{c}\text { Cellulose } \\
(\%)\end{array}$ & Hemicellulose (\%) & Lignin (\%) & $\begin{array}{c}\text { Levoglucosan } \\
\text { Concentration } \\
\left(\mathrm{mg} / \mathrm{m}^{3}\right) \\
\end{array}$ \\
\hline \multirow{8}{*}{ Indigenous } & M. indica (L) (Tarrsini et al. 2018) & 34.71 & 44.02 & 19.45 & 5.88 \\
\hline & A. heterophyllus (L) (Sasongko 2010) & 21.45 & & & 6.13 \\
\hline & C. nucifera (L) (Xu et al. 2015) & 33.29 & 33.61 & & 5.74 \\
\hline & M. indica $(\mathrm{W})$ & & & & 7.13 \\
\hline & A. heterophyllus (W) & & & & 7.45 \\
\hline & C. nucifera (W) (Mishra and Basu 2020) & $35-43$ & $14-24$ & $40-45$ & 6.63 \\
\hline & A. lebbeck (L) (Chitra and Balasubramanian 2016) & 25.96 & 9.38 & & 5.89 \\
\hline & S. mahagoni $(\mathrm{L})$ & & & & 6.31 \\
\hline \multirow[t]{4}{*}{ Exotic } & P. guajava (L) (Camarena et al. 2015) & $26.56-69.49$ & $11.02-34.12$ & $17.77-35.26$ & 6.19 \\
\hline & A. lebbeck (W) (Hassan et al. 2020) & $42.48-47.05$ & $16.19-19.60$ & & 8.76 \\
\hline & S. mahagoni (W) (Colares et al. 2015) & 57.25 & & 26.46 & 9.63 \\
\hline & P. guajava $(\mathrm{W})($ Camarena et al. 2015) & $26.56-69.49$ & $11.02-34.12$ & $17.77-35.26$ & 8.07 \\
\hline
\end{tabular}

The variation in levoglucosan concentrations were found due to the difference in the cellulose content of various plant species (Elias et al. 2001) and combustion efficiency of primary organic compounds like anhydrosugars to decompose into smaller secondary species (Engling et al. 2006). S. mahagoni $\left(9.63 \mathrm{mg} / \mathrm{m}^{3}\right)$ wood sample emitted maximum levoglucosan and C. nucifera $\left(5.74 \mathrm{mg} / \mathrm{m}^{3}\right)$ leaf sample emitted minimum. The exotic samples have a higher value of emitted levoglucosan than the indigenous samples. Comparatively, the leaf sample emits less levoglucosan than the wood sample. Indigenous soft leaf biomass samples emitted the least amount of levoglucosan, and the exotic hardwood samples emitted the highest amount of levoglucosan upon burning. The decreasing order of emitted levoglucosan concentration for all the plant sample is given below in Fig. 3.

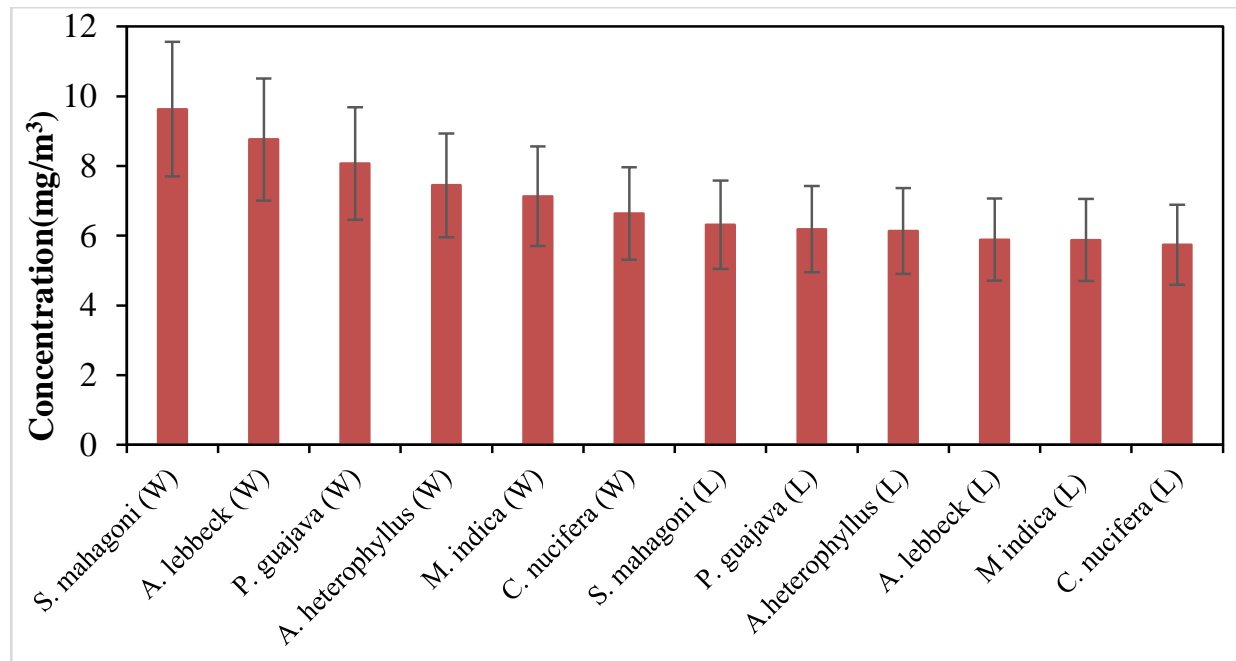

Fig. 3. Concentration of emitted levoglucosan in decreasing order. 
The average concentration of levoglucosan for indigenous plant samples is $6.49 \mathrm{mg} / \mathrm{m}^{3}$, and for the exotic plant samples are $7.48 \mathrm{mg} / \mathrm{m}^{3}$. The exotic plant samples showed 1.15 times greater emissions than the indigenous ones. Percentage of levoglucosan concentration for selected indigenous, and exotic plant samples are given in Fig. 4.

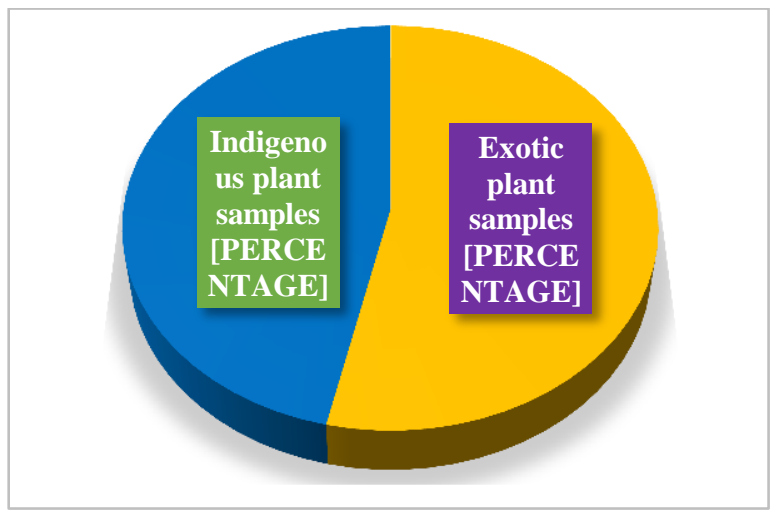

Fig. 4. Percentage of levoglucosan for indigenous and exotic plant samples.

For all the plant samples (indigenous and exotic), the concentration of emitted levoglucosan is always higher for the hardwood samples than the soft leaf samples. The leaf samples contain, on average, 10\%-12\% cellulose (Davis and Nielsen 1999). On the other hand, the cellulose content in wood samples is $40-50 \%$ on average (Chemical composition- ipst.gatech.edu). The average concentration of the dry leaf samples $\left(6.02 \mathrm{mg} / \mathrm{m}^{3}\right)$ is lower than the wood samples $\left(7.98 \mathrm{mg} / \mathrm{m}^{3}\right)$.
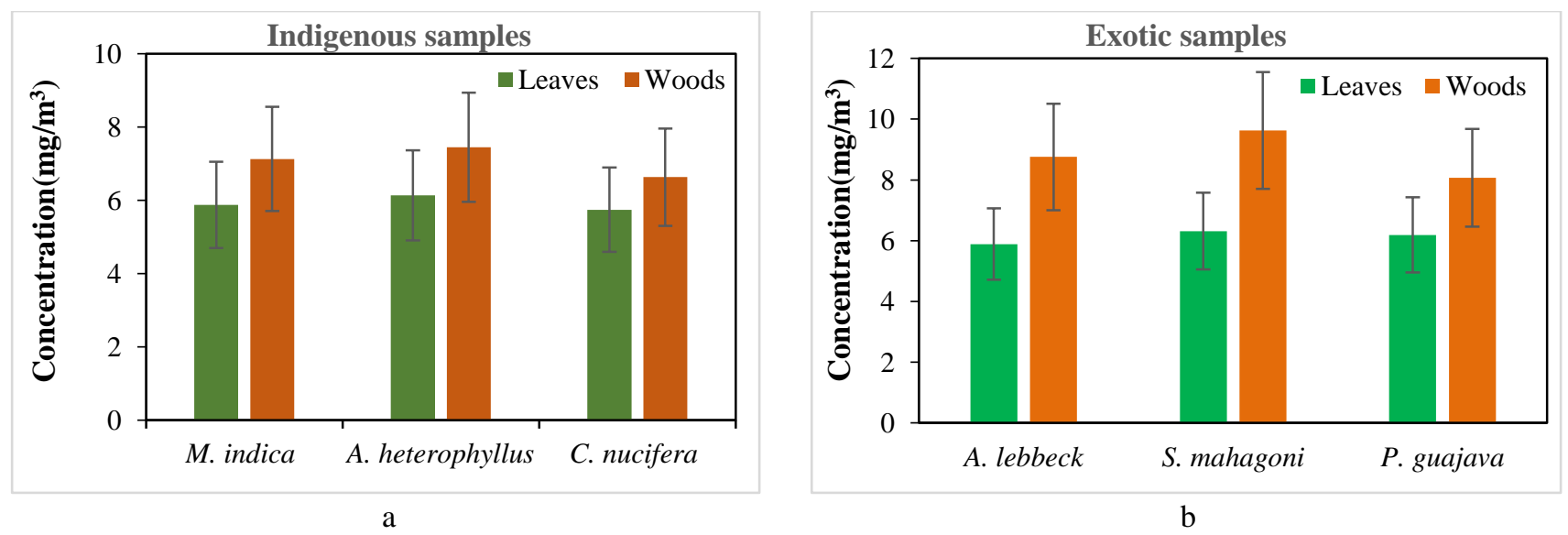

Fig. 5. Concentration of levoglucosan: a. Indigenous; and b. Exotic plant samples

M. indica and A. heterophyllus wood samples showed 1.21 times, and $C$. nucifera wood samples showed 1.15 times greater levoglucosan emission than their leave samples upon burning. Similarly, the A. lebbeck wood sample showed 1.49 times, and the $P$. guajava wood sample showed 1.30 times greater levoglucosan emission than their leave samples. S. mahagonay wood sample showed the highest emission of levoglucosan that is 1.53 times greater than its leave sample.

Each biomass sample was taken about $0.25 \mathrm{~kg}$, and particulate matter was collected for 2.5 minutes during the samples' burning. So, for all the samples $t_{\text {run }}=2.5 \mathrm{~min}$ and $\mathrm{m}_{\text {burned }}=0.25 \mathrm{~kg}$. 
Table 3. Emission factors of the plant samples upon burning.

\begin{tabular}{lccc}
\hline Sample & $\begin{array}{c}\mathbf{C}_{\mathbf{x}} \\
\left(\mathbf{m g} / \mathbf{m}^{\mathbf{3}}\right)\end{array}$ & $\begin{array}{c}\mathbf{Q}_{\text {chamber }} \\
\left(\mathbf{m}^{\mathbf{3}} \mathbf{m i n}^{-1}\right)\end{array}$ & $\begin{array}{c}\mathbf{E F}_{\mathbf{x}} \text { *10 } \\
(\mathbf{g} / \mathbf{k g})\end{array}$ \\
\hline M. indica (L) & 5.88 & 0.039 & 2.28 \\
A. heterophyllus (L) & 6.13 & 0.039 & 2.38 \\
C. nucifera (L) & 5.74 & 0.040 & 2.30 \\
M. indica (W) & 7.13 & 0.039 & 2.79 \\
A. heterophyllus (W) & 7.45 & 0.039 & 2.92 \\
C. nucifera (W) & 6.63 & 0.039 & 2.60 \\
A. lebbeck (L) & 5.89 & 0.040 & 2.32 \\
S. mahagoni (L) & 6.31 & 0.040 & 2.50 \\
P. guajava (L) & 6.19 & 0.037 & 2.28 \\
A. lebbeck (W) & 8.76 & 0.038 & 3.32 \\
S. mahagoni (W) & 9.63 & 0.040 & 3.81 \\
P. guajava (W) & 8.07 & 0.039 & 3.13 \\
\hline
\end{tabular}

The average values of emission factor for the exotic samples are $2.89 * 10^{-3} \mathrm{~g} / \mathrm{kg}$ and indigenous samples are $2.55^{*} 10^{-3} \mathrm{~g} / \mathrm{kg}$.

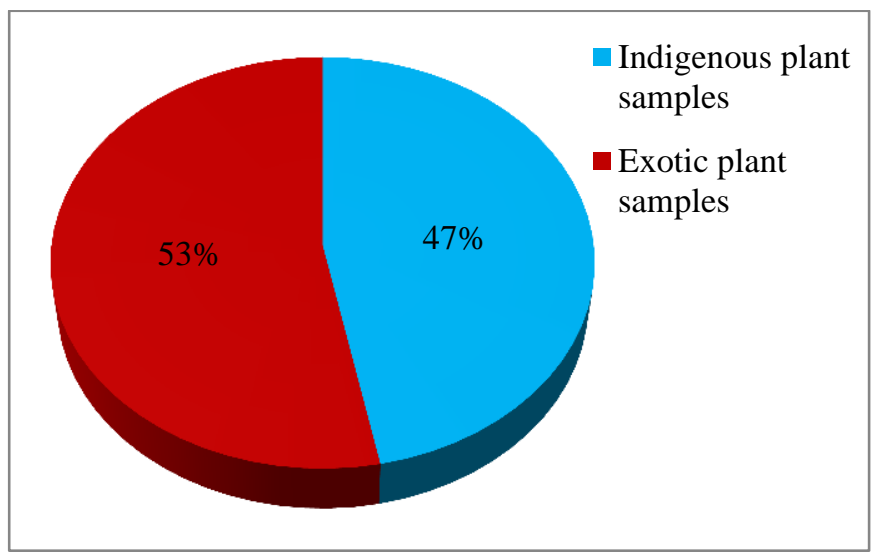

Fig. 6. Percentage of emission factor (EF) in indigenous and exotic plant samples.

The exotic plant samples showed 1.13 times higher emission factors for levoglucosan than indigenous plant samples. This study indicates that further research on more exotic and indigenous plant samples is required to determine which one produces highest amount of levoglucosan during burning.

The results of this study suggest that, among both indigenous and exotic plant species, exotic plant samples showed the highest amount of levoglucosan emissions after burning. The average concentration of levoglucosan emission for the exotic plant samples upon burning is $7.48 \mathrm{mg} / \mathrm{m}^{3}$, and indigenous plant samples are $6.49 \mathrm{mg} / \mathrm{m}^{3}$. The exotic samples showed 1.15 times greater emissions than the indigenous samples. S. mahagoni woods (exotic) released the largest concentrations of levoglucosan $\left(9.63 \mathrm{mg} / \mathrm{m}^{3}\right)$ and $C$. nucifera leaves (indigenous) released the lowest volume of levoglucosan $(5.74$ $\left.\mathrm{mg} / \mathrm{m}^{3}\right)$ in all samples. The average concentration of the dry leaf samples $\left(6.02 \mathrm{mg} / \mathrm{m}^{3}\right)$ is lower than the wood samples $\left(7.98 \mathrm{mg} / \mathrm{m}^{3}\right)$. The average emission factor for exotic plant samples $\left(2.89^{*} 10^{-}\right.$ $\left.{ }^{3} \mathrm{~g} / \mathrm{kg}\right)$ provides a higher rate than the indigenous plant samples $\left(2.55^{*} 10^{-3} \mathrm{~g} / \mathrm{kg}\right)$.

\section{ACKNOWLEDGEMENTS}

Authors acknowledge the help of Asma Shafiq, Asfay Raihan, Md. Shariful Islam, Md. Zakaria Islam during sampling. Authors are also thankful to Mr. Md. Halimur Rahman for helping chemical analysis. 


\section{REFERENCES}

Bhattarai, H., E. Saikawa, X. Wan, H. Zhu, K. Ram, S. Gao, S. Kang, Q. Zhang, Y. Zhang, G. Wu and X. Wang. 2019. Levoglucosan as a tracer of biomass burning: Recent progress and perspectives. Atmos. Res. 220: 2033.

Boguski, T. K. 2006. Understanding Units of Measurement. Environmental Science and Technology Briefs for Citizens. Issue 2. Center for Hazardous Substances Research, Kansas State University, Manhattan, USA. 3 pp.

Camarena-Tello, J. C., N. E. Rocha-Guzman, J. A. Gallegos-Infante, R. F. Gonzalez-Laredo, F. E. Pedraza-Bucio, P. Lopez-Albarran, R. Herrera-Bucio and J. G. Rutiaga-Quinones, 2015. Chemical composition of biomass generated in the guava tree pruning. EXCLI J. 14: 204.

Chitra, P. and A. A. Balasubramanian. 2016. Study on chemical composition and nutritive value of Albizia tree leaves as a livestock feed. Int. J. Sci. Environ. Technol. 5(6): 4638-4642.

Chemical composition of wood archived 2018-10-13 at the wayback Machine. ipst.gatech.edu.

Cofer III, W. R., J. S. Levine, E. L. Winstead and B. J. Stocks. 1991. Trace gas and particulate emissions from biomass burning in temperate ecosystems. In: J. S. Levine (ed.). Global biomass burning: Atmospheric, climatic, and biospheric implications. Massachusetts Inst. of Tech. Press; Cambridge, MA, USA., pp. 203208.

Colares, C. J., T. Pastore, V. T. Coradin, J. A. Camargos, A. C. Moreira, J. C. Rubim, and J. W. Braga. 2015. Exploratory analysis of the distribution of lignin and cellulose in woods by raman imaging and chemometrics. J. Brazilian Chem. Soc. 26(6): 1297-1305.

Cooper, C. and F. Alley. 1994. Air Pollution Control: A Design Approach. Waveland Pr. Inc., Long Grove, Illinois, USA. 839 pp.

Davis, D. L. and M. T. Nielsen. 1999. Tobacco-production, chemistry and technology. Oxon, Blackwell Science, USA. 480 pp.

dos Santos, C. Y. M., D. de Almeida Azevedo and F. R. de Aquino Neto. 2002. Selected organic compounds from biomass burning found in the atmospheric particulate matter over sugarcane plantation areas. Atmos. Environ. 36(18): 3009-3019.

Elias, V. O., B. R. Simoneit, R. C. Cordeiro and B. Turcq. 2001. Evaluating levoglucosan as an indicator of biomass burning in Caraias, Amazonia: A comparision to the charcoal record. Geochim. Cosmochim. Acta. 65(2): 267-272.

Engling, G., C. M. Carrico, S. M. Kreidenwis, J. L. Collett Jr., D. E. Day, W. C. Malm, E. Lincoln, W. M. Hao, Y. Iinuma and H. Herrmann. 2006. Determination of levoglucosan in biomass combustion aerosol by highperformance anion-exchange chromatography with pulsed amperometric detection. Atmos. Environ. 40: 299311.

Fartas, F. M., M. R. Othman, F. A. Rajeb and M. T. Latif. 2009. Determination of Levoglucosan in $\mathrm{PM}_{10}$ and biomass close burning residue samples using Anthronesulfuric acid colorimetric method. J. Appl. Sci. Res. 5(10): 1663-1667.

Fraser, M. P. and K. Lakshmanan. 2000. Using levoglucosan as a molecular marker for the long-range transport of biomass combustion aerosols. Environ. Sci. Technol. 34(21): 4560-4564.

Hassan, K. T. S. 2020. Vertical variation of wood chemical constituents in Albizia lebbeck L. Benth. (Trees grown in Egypt). J. Plant Product. 11(4): 363-367.

Holmes, B. J. and G. A. Petrucci. 2007. Oligomerization of levoglucosan by Fenton chemistry in proxies of biomass burning aerosols. J. Atmos. Chem. 58(2): 151-166.

Huda, A. S. N., S. Mekhilef and A. Ahsan. 2014. Biomass energy in Bangladesh; Current status and prospects. Renew. Sustain. Energy Rev. 30: 504-517. 
Janoszka, K., M. Czaplicka and K. Klejnowski. 2020. Comparison of biomass burning tracer concentrations between two winter seasons in Krynica Zdroj. Air Qual. Atmos. Health. 13(3): 379-385.

Jimenez, J., O. Farias, R. Quiroz and J. Yanez. 2017. Emission factors of particulate matter, polycyclic aromatic hydrocarbons and levoglucosan from wood combustion in south-central Chile. J. Air. Waste Manage. Associat. 67(7): 806-813.

Larsen III, R. K., M. M. Schantz and S. A. Wise. 2006. Determination of levoglucosan in particulate matter reference materials. Aerosol Sci. Technol. 40(10): 781-787.

Mishra, L. and G. Basu. 2020. Coconut fibre: its structure, properties and applications. In: Handbook of Natural fibers. Woodhead Publishing. pp. 231-255.

Naeher, L. P., M. Brauer, M. Lipsett, J. T. Zelikoff, C. D. Simpson, J. Q. Koenig and K. R. Smith. 2007. Woodsmoke health effects: a review. Inhal. Toxicol. 19(1): 67-106.

Puxbaum, H., A. Caserio, A. Sanchez-Ochoa, A. Kasper-Giebl, M. Claeys, A. Gelencser, M. Legrand, S. Preunkert and C. Pio. 2007. Levoglucosan levels at background sites in Europe for assessing the impact of biomass combustion on the European aerosol background. J. Geophys. Res. Atmos. 112(D23S05): 1-11.

Sasongko, W. T., L. M. Yusiati and Z. Bachruddin. 2010. Optimalisasi Pengikatan Tanin Daun Nangka dengan Protein Bovine Serum Albumin (Optimalisation Binding of Jackfruit Leaves Tannin with Bovine Serum Albumin Protein). Buletin Petenakan. 34(3): 154-158.

Schmidl, C., I. L. Marr, A. Caseiro, P. Kotianova, A. Berner, H. Bauer, A. Kasper-Giebl and H. Puxbaum. 2008. Chemical characterization of fine paricle emissions from wood stove combustion of common woods growing in mid-European Alpine regions. Atmos. Environ. 42(1): 126-141.

Schkolink, G. and Y. Rudich. 2006. Detection and quantification of levoglucosan in atmospheric aerosols: A review. Analytical Bioanalytical Chem. 385(1): 26-33.

Simoneit, B. R., J. J. Schauer, C. G. Nolte, D. R. Oros, V. O. Elias, M. P. Fraser, W. F. Rogge and G. R. Cass. 1999. Levoglucosan a tracer for cellulose in biomass burning and atmospheric particles. Atmos. Environ. 33(2): 173-182.

Simoneit, B. R. 2002. Biomass burning-a review of organic tracers for smoke from incomplete combustion. Appl. Geochem. 17(3): 129-162.

Simoneit, B. R., M. Kobayashi, M. Mochida, K. Kawamura, M. Lee, H. J. Lim, B. J. Turpin and Y. Komazaki. 2004. Composition and major sources of organic compounds of aerosol particulate matter sampled during the ACE-Asia campaign. J. Geophys. Res. Atmos. 109(D19S10): 1-22.

Tarrsini, M., Y. P. Teoh, Q. H. Ng, B. Kunasundari, Z. X. Ooi, H. S. Shuit and P. Y. Hoo. 2018, March. Practicability of lignocellulosic waste composite in controlling air pollution from leaves litter through bioethanol production. In: IOP Conference Series: Materials Science and Engineering. Vol. 318. $012001 \mathrm{pp}$.

Ward, D. E. and C. C. Hardy. 1991. Smoke emissions from wildland fires. Environ. Int. 17(2-3): 117-134.

Xu, C., S. Zhu, C. Xing, D. Li, N. Zhu and H. Zhou. 2015. Isolation and properties of cellulose nanofibrils from coconut palm petioles by different mechanical process. PLoS One. 10(4): 122-123.

Yemm, E. W. and A. Wills. 1954. The estimation of carbohydrates in plant extracts by anthrone. Biochem. J. 57(3): 508-514.

Zdrahal, Z., J. Oliveira, R. Vermeylen, M. Claeys and W. Maenhaut. 2002. Improved method for quantifying levoglucosan and related monosaccharide anhydrides in atmospheric aerosols and application to samples from urban and tropical locations. Environ. Sci. Technol. 36(4): 747-753. 